\title{
Aureibacter tunicatorum gen. nov., sp. nov., a marine bacterium isolated from a coral reef sea squirt, and description of Flammeovirgaceae fam. nov.
}

Correspondence

Jaewoo Yoon

jwyoon@kmu.ac.kr

\author{
Jaewoo Yoon, ${ }^{1}$ Kyoko Adachi, ${ }^{2} \dagger$ Sanghwa Park, ${ }^{3}$ Hiroaki Kasai ${ }^{2} \ddagger$ \\ and Akira Yokota ${ }^{3}$ \\ ${ }^{1}$ College of Pharmacy, Keimyung University, 2800 Dalgubeoldaero, Dalseo-Gu, Daegu 704-701, \\ Republic of Korea \\ ${ }^{2}$ Marine Biotechnology Institute, 3-75-1 Heita, Kamaishi, Iwate 026-0001, Japan \\ ${ }^{3}$ Institute of Molecular and Cellular Biosciences, University of Tokyo, 1-1-1 Yayoi, Bunkyo-ku, \\ Tokyo 113-0032, Japan
}

\begin{abstract}
Two aerobic, Gram-reaction-negative, golden-yellow pigmented and rod-shaped bacteria, designated strains A5Q-118 ${ }^{\top}$ and A5Q-27, were isolated from an unidentified sea squirt that thrives in the coral reefs off the coast of Okinawa, Japan. Phylogenetic analyses based on the $16 \mathrm{~S}$ rRNA gene sequence revealed that the novel isolates were affiliated with the family

'Flammeovirgaceae' of the phylum Bacteroidetes. Strains A5Q-118' and A5Q-27 shared $100 \%$ sequence similarity with each other and showed $<92 \%$ similarity with other cultivated members of the family 'Flammeovirgaceae'. The novel isolates were phenotypically and physiologically different from strains described previously. The DNA G +C content was 35.5-36.2 mol\%, MK-7 was the major menaquinone and iso- $\mathrm{C}_{15: 0}$ and $\mathrm{C}_{16: 1} \omega 5 \mathrm{c}$ were the major fatty acids. Based on the results of this polyphasic taxonomic study, it was concluded that strains A5Q-118 ${ }^{\top}$ and A5Q27 represent a novel species in a new genus of the family 'Flammeovirgaceae', for which the name Aureibacter tunicatorum gen. nov., sp. nov. is proposed. Proposal for designation of the Flammeovirgaceae fam. nov. is also presented. The type strain of Aureibacter tunicatorum is A5Q $-118^{\top}\left(=\right.$ KCTC $23232^{\top}=$ NBRC $\left.107587^{\top}\right)$.
\end{abstract}

Members of the phylum Bacteroidetes (Ludwig \& Klenk, 2001), also known as the Bacteroides-Cytophaga-Flexibacter group, are widely distributed over a diverse range of ecological niches (Bowman et al., 1997; DeLong et al., 1993; Glöckner et al., 1999; O'Sullivan et al., 2002; Pinhassi et al., 1997). According to several reports, members of the phylum Bacteroidetes have been implicated as being major utilizers of high-molecular-mass organic matter dissolved in marine ecosystems (Cottrell \& Kirchman, 2000) and are often abundant in nutrient-rich waters where biomacromolecules accumulate (Reichenbach, 1989). In spite of their wide ecological distribution in nature, the classification of the

tPresent address: Basic Research Laboratories, Nippon Steel Chemical, 1 Tsukiji, Kisarazu, Chiba 292-0835, Japan.

‡Present address: Marine Biosciences Kamaishi Research Laboratory, Kitasato University, 3-75-1 Heita, Kamaishi, Iwate 026-0001, Japan.

Abbreviations: MP, maximum-parsimony; NJ, neighbour-joining; TEM, transmission electron microscopy.

The GenBank/EMBL/DDBJ accession number for the 16S rRNA gene sequence of strain $A 5 Q-118^{\top}$ is $A B 572584$. phylum Bacteroidetes is still in a state of flux. For formal classification of the phylum Bacteroidetes, representatives that thrive in a wide range of terrestrial, aquatic and marine habitats need to be be isolated, cultivated and taxonomically investigated. At the time of writing, the family 'Flammeovirgaceae' within the phylum Bacteroidetes, incorporated the genera Flammeovirga, Flexithrix, Limibacter, Perexilibacter, Persicobacter, Rapidithrix and Sediminitomix. An emended description of the genus Persicobacter was also recently published (Muramatsu et al., 2010).

Two strains, designated A5Q-118 ${ }^{\mathrm{T}}$ and $\mathrm{A} 5 \mathrm{Q}-27$, were isolated from an unidentified sea squirt collected near Iriomote Island, Okinawa, Japan. A piece of sea squirt $\left(\sim 1 \mathrm{~cm}^{3}\right)$ was gently rinsed in sterile artificial seawater and then homogenized with a sterilized glass rod. The suspension was plated onto marine agar 2216 (Difco) adjusted to pH 11 with $\mathrm{Na}_{2} \mathrm{CO}_{3}$ and $\mathrm{NaHCO}_{3}$. A colony was transferred onto a 1/3 strength marine agar 2216 plate to purify the isolate for use in this study. In the present study, we determined the phylogenetic position of strains A5Q-118 ${ }^{\mathrm{T}}$ and A5Q-27 and used a polyphasic taxonomic 
approach, including analysis of $16 \mathrm{~S}$ rRNA gene sequences, fatty acid compositions and quinones as well as genotypic and physiological properties, to characterize the organisms. Based on these data, it is proposed that the isolates represent a novel genus of the family 'Flammeovirgaceae' in the phylum Bacteroidetes.

Temperature and $\mathrm{pH}$ ranges for growth were determined on marine agar 2216. Salt tolerance was tested on marine agar 2216 containing $0-10 \%(\mathrm{w} / \mathrm{v}) \mathrm{NaCl}$. Gram-staining was performed as described by Murray et al. (1994). Cell morphology was observed using light microscopy (BX60; Olympus) and transmission electron microscopy (TEM). Gliding motility was determined as described by Perry (1973). For the TEM observations, cells were mounted on Formvar-coated copper grids and negatively stained with $1 \%(\mathrm{w} / \mathrm{v})$ aqueous uranyl acetate. Grids were observed in a JEOL 1010 transmission electron microscope (JEOL) operated at $100 \mathrm{kV}$. Growth under anaerobic conditions was determined after 2 weeks of incubation on marine agar 2216 in an AnaeroPack (Mitsubishi Gas Chemical). Catalase activity was determined by bubble formation in a $3 \%$ hydrogen peroxide solution. Oxidase activity was determined by using cytochrome oxidase paper (Nissui Pharmaceutical). API 20 E, API $50 \mathrm{CH}$ and API ZYM strips (bioMérieux) were used to determine physiological and biochemical characteristics. All suspension media for API test strips were supplemented with $0.85 \%(\mathrm{w} / \mathrm{v}) \mathrm{NaCl}$ (final concentration). The API $20 \mathrm{E}$ and API $50 \mathrm{CH}$ tests were read after $72 \mathrm{~h}$ of incubation at $30{ }^{\circ} \mathrm{C}$ and API ZYM tests were read after $4 \mathrm{~h}$ of incubation at $37{ }^{\circ} \mathrm{C}$. Preparation and identification of isoprenoid quinones was carried out at the TechnoSuruga Lab as described previously (Nishijima et al., 1997). GC analysis of cellular fatty acid methyl esters was performed using a culture grown on marine agar 2216 at $30{ }^{\circ} \mathrm{C}$ for $48 \mathrm{~h}$ according to the instructions of the Microbial Identification System (MIDI). DNA was prepared according to the method of Marmur (1961) from cells grown on marine agar 2216 medium and the DNA base composition was determined at the TechnoSuruga Lab by using the HPLC method of Katayama-Fujimura et al. (1984). A $\sim 1500$ bp fragment of the 16S rRNA gene was amplified from the extracted DNA by using the bacterial universal primers $27 \mathrm{~F}$ and $1492 \mathrm{R}$, which are specific to the 16S rRNA gene (based on the Escherichia coli numbering system; Weisburg et al., 1991). To ascertain the phylogenetic position of the new isolates, the $16 \mathrm{~S}$ rRNA gene sequences of strains A5Q- $118^{\mathrm{T}}$ and A5Q-27 were compared with the sequences obtained from GenBank (http://www.ncbi.nlm.nih.gov). Multiple alignments of the sequences were performed using CLUSTAL_X (version 1.83) (Thompson et al., 1997). Alignment gaps and ambiguous bases were not taken into consideration when the 1322 bases of 16S rRNA gene nucleotides were compared. Aligned sequences were analysed by using MEGA4.0 software (Tamura et al., 2007). Evolutionary distances (distance options according to the Kimura two-parameter model; Kimura, 1983) and clustering, using the neighbour-joining (NJ) (Saitou \& Nei, 1987) and maximum-parsimony (MP) (Fitch, 1971) methods, were determined by using bootstrap values based on 1000 replications (Felsenstein, 1985). Similarity values were calculated using the same software.

In the course of TEM, cells of various sizes were observed. Cells were mostly straight and rod-shaped. Cells were $0.4-$ $0.5 \times 3.5$ and 4.5 in size, gliding motility was not observed and flagella were not seen (Fig. 1).

Comparative phylogenetic analysis of $16 \mathrm{~S}$ rRNA gene sequences revealed that strains A5Q- $118^{\mathrm{T}}$ and A5Q-27 were affiliated with the family 'Flammeovirgaceae' within the phylum Bacteroidetes with a bootstrap confidence value of $100 \%$ using the NJ method (Fig. 2). Analysis of $16 \mathrm{~S}$ rRNA gene sequences indicated that the sequences of strains A5Q- $118^{\mathrm{T}}$ and A5Q-27 were identical to one another and showed the highest sequence similarity $(91.4 \%)$ to Persicobacter psychrovividus Asr22-19 $9^{\mathrm{T}}$ (Muramatsu et al., 2010), followed by Persicobacter diffluens NBRC $15940^{\mathrm{T}}$ (90.8\%; Nakagawa et al., 1997), Flexithrix dorotheae NBRC $15987^{\mathrm{T}}$ (84.9\%; Lewin, 1970), Flammeovirga aprica NBRC $15941^{\mathrm{T}}$ (84.4\%; Takahashi et al., 2006), Sediminitomix flava NBRC $101625^{\mathrm{T}}(83.6 \%$; Khan et al., 2007) and Limibacter armeniacum KCTC $22132^{\mathrm{T}}$ (83.2 \%; Yoon et al., 2008). All other species of the family 'Flammeovirgaceae' with validly published names were more distantly related, showing 16S rRNA gene sequence similarity values $<83.5 \%$.

As shown in Table 1, the predominant cellular fatty acids of strains $\mathrm{A} 5 \mathrm{Q}-118^{\mathrm{T}}$ and $\mathrm{A} 5 \mathrm{Q}-27$ differentiate it from recognized species of the genera Flammeovirga, Limibacter, Perexilibacter, Rapidithrix and Sediminitomix based on the proportions of $\mathrm{C}_{13: 1} \omega 1 c(1-6.8 \%)$, iso- $\mathrm{C}_{15: 0}(26.9-33.3 \%)$, $\mathrm{C}_{16: 1} \omega 5 c(11-17.3 \%), \mathrm{C}_{16: 0} 3-\mathrm{OH}(7.6-16.1)$ and iso- $\mathrm{C}_{17: 0}$ $3-\mathrm{OH}(5-11 \%)$. In addition to this, the two novel isolates showed distinct phenotypic features that distinguished them from their closest relatives (Table 2).

Based on the results of the phylogenetic analysis and on their biochemical and physiological properties, strains A5Q- $-118^{\mathrm{T}}$ and $\mathrm{A} 5 \mathrm{Q}-27$, isolated from an unidentified sea squirt collected

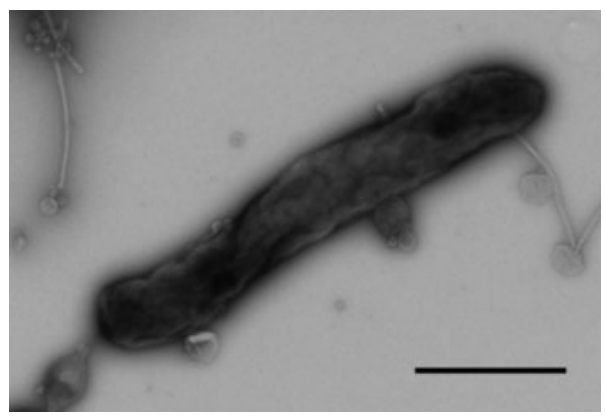

Fig. 1. Transmission electron micrograph of a negatively stained cell of strain A5Q-118 ${ }^{\top}$. Bar, $1 \mu \mathrm{m}$. 


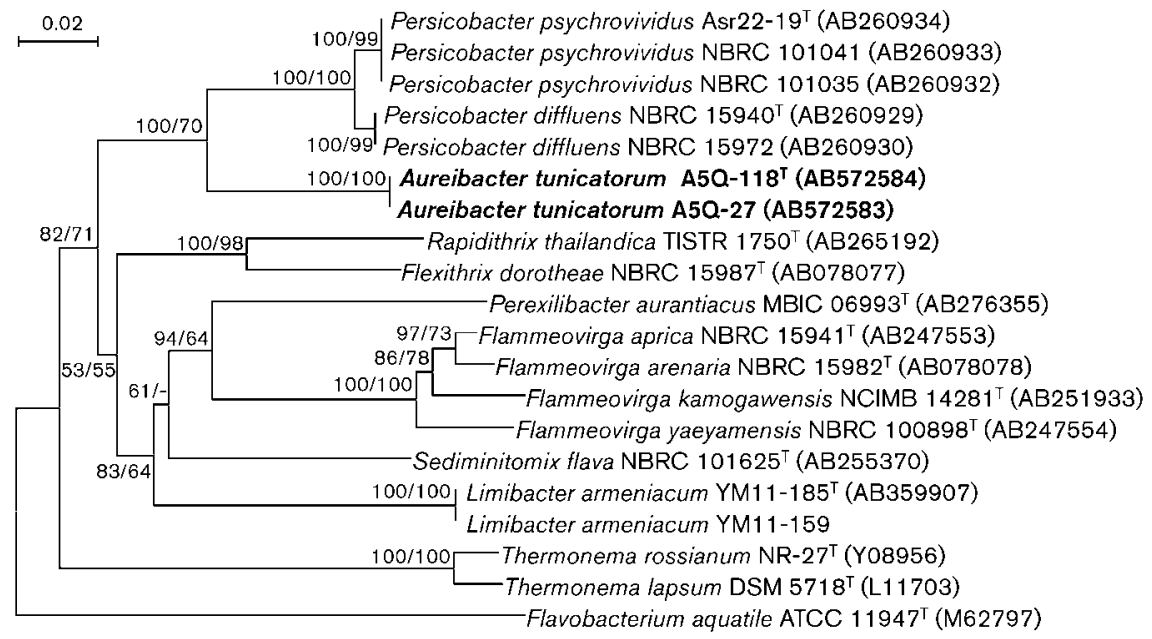

Fig. 2. Neighbour-joining tree based on $16 \mathrm{~S}$ rRNA gene sequences showing the phylogenetic positions of strains $A 5 Q-118^{\top}$ and A5Q-27 and representatives of closely related and other more distantly related taxa. Bootstrap values $>50 \%$ (based on 1000 replications) from both neighbour-joining and maximum-parsimony analyses are shown, respectively; '-' indicates a branch not found or sufficiently supported by bootstrap analysis. The tree was rooted using Flavobacterium aquatile ATCC $11947^{\top}$ as an outgroup. Bar, $2 \%$ sequence divergence.

near Iriomote Island in Japan, represent a novel species of a new genus in the family 'Flammeovirgaceae' within the phylum Bacteroidetes, for which the name Aureibacter tunicatorum gen. nov., sp. nov. is proposed.

\section{Description of Flammeovirgaceae fam. nov.}

Flammeovirgaceae (Flam.me.o.vir.ga'ce.ae. N.L. fem. n. Flammeovirga type genus of the family; -aceae ending to denote a family; N.L fem. pl. n. Flammeovirgaceae the Flammeovirga family).

Encompasses Gram-negative bacteria retrieved mainly from soil and marine environments. At the time of writing, the family comprises the genera Aureibacter, Flammeovirga, Flexithrix, Limibacter, Perexilibacter, Persicobacter, Rapidithrix and Sediminitomix. Delineation of the family is determined primarily by phylogenetic information from

Table 1. Fatty acid contents of strains $A 5 Q-118^{\top}$ and A5Q-27 and members of related taxa

Taxa: 1, strain A5Q-118 ${ }^{\mathrm{T}}$; 2, strain A5Q-27; 3, Persicobacter (data from Muramatsu et al., 2010); 4, Flammeovirga (Takahashi et al., 2006; Hosoya \& Yokota, 2007); 5, Sediminitomix flava NBRC $101625^{\mathrm{T}}$ (Khan et al., 2007); 6, Limibacter armeniacum YM11-185 ${ }^{\mathrm{T}}$ (Yoon et al., 2008); 7 , L. armeniacum YM11-159 (Yoon et al., 2008); 8, Perexilibacter aurantiacus MBIC06993 ${ }^{\mathrm{T}}$ (Yoon et al., 2007); 9, Rapidithrix thailandica TISTR $1750^{\mathrm{T}}$ (Srisukchayakul et al., 2007). Values are percentages of total fatty acid contents. -, Not detected; tr, trace.

\begin{tabular}{|c|c|c|c|c|c|c|c|c|c|}
\hline Fatty acid & 1 & 2 & 3 & 4 & 5 & 6 & 7 & 8 & 9 \\
\hline $\mathrm{C}_{13: 1} \omega 1 c$ & 6.8 & 1.0 & - & $0.8-2.9$ & - & 1.6 & 1.0 & 1.6 & - \\
\hline $\mathrm{C}_{14: 0}$ & 1.9 & 1.6 & $1.0-2.0$ & $3.7-9.0$ & 5.0 & 1.1 & 1.0 & 1.9 & 1.2 \\
\hline iso- $\mathrm{C}_{15: 0}$ & 33.3 & 26.9 & $47.7-55.6$ & $21.2-54.3$ & 23.0 & 28.1 & 26.9 & 50.6 & 6.3 \\
\hline $\mathrm{C}_{15: 0}$ & $\operatorname{tr}$ & $\operatorname{tr}$ & - & $\operatorname{tr}-7.1$ & - & 1.7 & $\operatorname{tr}$ & 1.4 & $\operatorname{tr}$ \\
\hline $\mathrm{C}_{16: 1} \omega 7 c$ alcohol & - & - & - & - & - & 2.3 & 4.2 & - & - \\
\hline iso- $\mathrm{C}_{16: 1} \mathrm{H}$ & - & - & - & $\operatorname{tr}-3.2$ & - & 2.2 & 3.1 & - & - \\
\hline $\mathrm{C}_{16: 0} \mathrm{~N}$ alcohol & - & - & - & $\operatorname{tr}-1.8$ & - & 3.2 & 10.0 & - & - \\
\hline $\mathrm{C}_{16: 1} \omega 7 c$ & - & - & - & - & - & 23.2 & 16.8 & 16.7 & 1.5 \\
\hline $\mathrm{C}_{16: 1} \omega 5 c$ & 11 & 17.3 & $1.3-4.2$ & $1.8-4.7$ & 21.0 & 9.9 & 7.9 & 4.9 & 44.8 \\
\hline $\mathrm{C}_{16: 0}$ & 10.6 & 5.0 & $4.6-9.4$ & $2.8-4.8$ & 6.0 & 3.5 & 4.4 & 3.76 & 4.0 \\
\hline iso- $\mathrm{C}_{15: 0} 3-\mathrm{OH}$ & 1.0 & 1.2 & $3.2-7.6$ & $3.9-5.5$ & 2.0 & 3.7 & 2.4 & 2.2 & 4.3 \\
\hline iso- $\mathrm{C}_{17: 1} \omega 9 c$ & - & - & - & - & - & 1.6 & 1.2 & - & - \\
\hline $\mathrm{C}_{17: 1} \omega 6 c$ & - & $\operatorname{tr}$ & - & - & - & 1.0 & $\operatorname{tr}$ & $\operatorname{tr}$ & - \\
\hline $\mathrm{C}_{16: 0} 3-\mathrm{OH}$ & 7.6 & 16.1 & $3.9-6.5$ & $4.1-14.6$ & 18.0 & 4.9 & 2.8 & 2.2 & 3.8 \\
\hline iso- $\mathrm{C}_{17: 0} 3-\mathrm{OH}$ & 5.0 & 11.0 & $6.6-16.8$ & $2.0-2.4$ & 2.0 & 4.5 & 3.5 & 2.4 & 10.8 \\
\hline
\end{tabular}


Table 2. Characteristics that differentiate strains $A 5 Q-118^{\top}$ and A5Q-27 from members of related taxa

Taxa: 1, strain A5Q-118 ${ }^{\mathrm{T}}$; 2, strain A5Q-27; 3, Persicobacter psychrovividus (data from Muramatsu et al., 2010); 4, P. diffluens (Muramatsu et al., 2010); 5, Flexithrix dorothea ATCC 23163 ${ }^{\mathrm{T}}$ (Lewin, 1970); 6, Flammeovirga aprica NBRC 15941 ${ }^{\mathrm{T}}$ (Takahashi et al., 2006); 7, F. arenaria NBRC $15982^{\mathrm{T}}$ (Yoon et al., 2008); 8, F. yaeyamensis NBRC 100898 ${ }^{\mathrm{T}}$ (Takahashi et al., 2006); 9, F. kamogawensis NCIMB $14281^{\mathrm{T}}$ (Hosoya \& Yokota, 2007); 10, Sediminitomix flava NBRC 101625 (Khan et al., 2007); 11, Limibacter armeniacum YM11-185 ${ }^{\mathrm{T}}$ (Yoon et al., 2008); 12, L. armeniacum YM11-159 (Yoon et al., 2008); 13, Perexilibacter aurantiacus MBIC06993 $3^{\mathrm{T}}$ (Yoon et al., 2007); 14, Rapidithrix thailandica TISTR $1750^{\mathrm{T}}$ (Srisukchayakul et al., 2007). +, Positive; $\mathrm{w}$, weakly positive; v, variable; - , negative; ND, no data.

\begin{tabular}{|c|c|c|c|c|c|c|c|c|c|c|c|c|c|c|}
\hline Characteristic & 1 & 2 & 3 & 4 & 5 & 6 & 7 & 8 & 9 & 10 & 11 & 12 & 13 & 14 \\
\hline Isolation source & Sea squirt & Sea squirt & Shellfish & Mud & Seashore silt & Marine & Marine & Marine & $\begin{array}{l}\text { Coastal } \\
\text { seawater }\end{array}$ & $\begin{array}{l}\text { Marine } \\
\text { sediment }\end{array}$ & $\begin{array}{l}\text { Marine } \\
\text { sediment }\end{array}$ & $\begin{array}{l}\text { Marine } \\
\text { sediment }\end{array}$ & $\begin{array}{l}\text { Marine } \\
\text { sediment }\end{array}$ & $\begin{array}{c}\text { Marine } \\
\text { algae }\end{array}$ \\
\hline Colony colour & $\begin{array}{l}\text { Golden } \\
\text { yellow }\end{array}$ & $\begin{array}{l}\text { Golden } \\
\text { yellow }\end{array}$ & Orange & $\begin{array}{l}\text { Pink to } \\
\text { orange }\end{array}$ & $\begin{array}{l}\text { Bright golden } \\
\text { yellow }\end{array}$ & $\begin{array}{c}\text { Orange to } \\
\text { reddish } \\
\text { orange }\end{array}$ & $\begin{array}{c}\text { Orange to } \\
\text { reddish } \\
\text { orange }\end{array}$ & $\begin{array}{c}\text { Orange to } \\
\text { reddish } \\
\text { orange }\end{array}$ & $\begin{array}{l}\text { Reddish } \\
\text { orange }\end{array}$ & Orange & $\begin{array}{l}\text { Apricot to } \\
\text { pale-orange }\end{array}$ & $\begin{array}{l}\text { Apricot to } \\
\text { pale-orange }\end{array}$ & $\begin{array}{l}\text { Dull } \\
\text { orange }\end{array}$ & $\begin{array}{c}\text { Light olive } \\
\text { grey }\end{array}$ \\
\hline Cell morphology & Rods & Rods & Rods & Rods & Rods & Long rods & Long rods & Long rods & Long rods & Long rods & Long rods & Long rods & Rods & $\begin{array}{l}\text { Flexible } \\
\text { filaments }\end{array}$ \\
\hline Cell length $(\mu \mathrm{m})$ & $3.5-4.5$ & $3.5-4.5$ & $0.9-6$ & $0.9-30$ & $5-15$ & $1.7-96$ & $2-40$ & $1.7-90$ & $2.0-40$ & $10-35$ & $15-40$ & $15-40$ & $10-20$ & $20-100$ \\
\hline Cell width $(\mu \mathrm{m})$ & $0.4-0.5$ & $0.4-0.5$ & $0.4-0.6$ & $0.4-0.5$ & 0.7 & $0.5-0.9$ & $0.5-0.9$ & $0.4-0.9$ & $0.6-1.0$ & $0.5-0.7$ & $0.3-0.5$ & $0.3-0.5$ & $0.3-0.5$ & 0.7 \\
\hline Catalase & + & + & + & + & - & + & - & $\mathrm{V}$ & + & + & + & + & $\mathrm{W}$ & - \\
\hline \multicolumn{15}{|l|}{ Hydrolysis of: } \\
\hline Agar & - & - & + & + & - & + & + & + & + & $\mathrm{W}$ & - & - & - & $\mathrm{ND}$ \\
\hline Starch & - & + & $\mathrm{W}$ & $\mathrm{W}$ & - & + & + & + & + & + & - & - & - & $\mathrm{ND}$ \\
\hline DNA & - & - & $\mathrm{ND}$ & + & $\mathrm{ND}$ & + & - & + & + & + & - & - & - & $\mathrm{ND}$ \\
\hline $\begin{array}{l}\text { Max. temperature } \\
\text { for growth }\left({ }^{\circ} \mathrm{C}\right)\end{array}$ & 37 & 35 & 45 & 45 & 35 & 30 & 30 & 35 & 30 & 40 & 37 & 45 & 43 & $\mathrm{ND}$ \\
\hline $\begin{array}{l}\mathrm{NaCl} \text { range for } \\
\text { growth }(\%, \mathrm{w} / \mathrm{v})\end{array}$ & $1-5$ & $1-7$ & 7 & 7 & $1-6$ & $1-5$ & $1-5$ & $1-5$ & $2-4$ & $1-4$ & $1-6.5$ & $1-6.5$ & $0-3.5$ & $\mathrm{ND}$ \\
\hline $\begin{array}{l}\text { DNA G }+ \text { C } \\
\text { content }(\mathrm{mol} \%)\end{array}$ & 36.2 & 35.5 & $42-42.7$ & $42.6-43.8$ & 37 & 34.2 & 31.8 & $33.4-35.7$ & $32-33$ & 38 & 27.9 & 27.8 & 43 & 40 \\
\hline
\end{tabular}


$16 \mathrm{~S}$ rRNA gene sequences. Cells are rod-shaped, chemoheterotrophic and aerobic. The DNA G $+\mathrm{C}$ contents of members of the family are $27-43 \mathrm{~mol} \%$. The type genus of the family is Flammeovirga Takahashi et al. 2006.

\section{Description of Aureibacter gen. nov.}

Aureibacter (Au.re.i.bac'ter. L. adj. aureus golden; N.L. masc. n. bacter rod; N.L. masc. n. Aureibacter golden rod).

Cells are rod-shaped, Gram-reaction-negative, aerobic and do not form endospores. Catalase- and oxidase-positive. Nitrate and nitrite reduction are negative. The major respiratory menaquinone is MK-7. Predominant cellular fatty acids are iso- $\mathrm{C}_{15: 0}$ and $\mathrm{C}_{16: 1} \omega 5 c$.

The type species of the genus is Aureibacter tunicatorum.

\section{Description of Aureibacter tunicatorum sp. nov.}

Aureibacter tunicatorum (tu.ni.ca'to.rum. N.L. gen. pl. n. tunicatorum of Tunicata, isolated from tunicates).

Characteristics are the same as those given in the genus description with the following additions. Cells are long rods, $0.4-0.5 \times 3.5-4.5 \mu \mathrm{m}$. Non-motile. No gliding motility is observed. Colonies grown on marine agar 2216 are circular, convex and golden-yellow. Grows at $20-37^{\circ} \mathrm{C}$ (optimum $\sim 30{ }^{\circ} \mathrm{C}$ ) but not 4 or $45^{\circ} \mathrm{C}$, at $\mathrm{pH} 6-9$ (optimum $\sim \mathrm{pH} 7$ ) and in up to $7 \%(\mathrm{w} / \mathrm{v}) \mathrm{NaCl}$. $\mathrm{NaCl}$ is required for growth but seawater is not. Gelatin and starch are hydrolysed but agar and DNA are not. Positive for $o$-nitrophenyl- $\beta$-D-galactosidase (ONPG) and the production of lysine decarboxylase and tryptophan deaminase. Negative for the VogesProskauer reaction, citrate utilization and production of arginine dihydrolase, ornithine decarboxylase, hydrogen sulfide and indole. Acid is produced from galactose, glucose, aesculin ferric citrate, fructose, melibiose, mannose, sucrose, trehalose, turanose, D-lyxose, D-tagatose and 5-ketogluconate but not from $\mathrm{D}$-arabinose, L-arabinose, ribose, D-xylose, L-xylose, methyl- $\beta$-D-xylopyranoside, rhamnose, methyl$\alpha$-D-mannnopyranoside, methyl- $\alpha$-D-glucopyranoside, $N$ acetylglucosamine, amygdalin, arbutin, salicin, cellobiose, maltose, lactose, melezitose, inulin, raffinose, gentiobiose, Dand L-fucose, glycerol, erythritol, adonitol, sorbose, dulcitol, inositol, mannitol, sorbitol, starch, glycogen, xylitol, D- and L-arabitol, gluconate or 2-ketogluconate. Alkaline phosphatase, esterase (C4), esterase lipase (C8), leucine arylamidase, valine arylamidase, cystine arylamidase, trypsin, chymotrypsin, acid phosphatase, naphthol-AS-BI-phosphohydrolase and $N$-acetyl- $\beta$-glucosaminidase activities are positive but lipase (C4), $\alpha$ - and $\beta$-galactosidase, $\beta$-glucuronidase, $\alpha$ - and $\beta$-glucosidase, $\alpha$-mannosidase and $\alpha$-fucosidase activities are negative. Major fatty acid components $(>1.0 \%)$ include $\mathrm{C}_{10: 0}(3.8 \%), \mathrm{C}_{13: 1} \omega 1 c(6.8 \%), \mathrm{C}_{14: 0}(1.9 \%)$, iso- $\mathrm{C}_{15: 0}$ (33.3\%), $\mathrm{C}_{16: 1} \omega 5 c(11 \%), \mathrm{C}_{16: 0}(10.6 \%)$, iso- $\mathrm{C}_{15: 0} 3-\mathrm{OH}$ (1\%), anteiso- $\mathrm{C}_{17: 1} \omega 9 c(3.3 \%)$, iso- $\mathrm{C}_{16: 0} 3-\mathrm{OH}(4 \%)$, $\mathrm{C}_{16: 0} 3-\mathrm{OH}(7.6 \%)$, iso- $\mathrm{C}_{17: 0} 3-\mathrm{OH}(5 \%)$ and $\mathrm{C}_{20: 4} \omega 6,9$, $12,15 c(2.2 \%)$.
The type strain, A5Q- $118^{\mathrm{T}}\left(=\mathrm{KCTC} 23232^{\mathrm{T}}=\mathrm{NBRC}\right.$ $107587^{\mathrm{T}}$ ), was isolated from an unidentified sea squirt collected near Iriomote Island, Okinawa, Japan. The G + C content of the genomic DNA of the type strain is $36.2 \mathrm{~mol} \%$.

\section{Acknowledgements}

The authors are grateful to Atsuko Katsuta for her technical assistance. We thank Dr J. Euzéby for advice on the Latin etymology. This work was supported by the New Energy and Industrial Technology Development Organization (NEDO). This work was supported, in part, by a research grant from the Institute for Fermentation, Osaka, Japan, (grant no. 2009-2011).

\section{References}

Bowman, J. P., McCammon, S. A., Brown, M. V., Nichols, D. S. \& McMeekin, T. A. (1997). Diversity and association of psychrophilic bacteria in Antarctic sea ice. Appl Environ Microbiol 63, 3068-3078.

Cottrell, M. T. \& Kirchman, D. L. (2000). Community composition of marine bacterioplankton determined by $16 \mathrm{~S}$ rRNA gene clone libraries and fluorescence in situ hybridization. Appl Environ Microbiol 66, 5116-5122.

DeLong, E. F., Franks, D. G. \& Alldredge, A. L. (1993). Phylogenetic diversity of aggregate-attached vs. free-living marine bacterial assemblages. Limnol Oceanogr 38, 924-934.

Felsenstein, J. (1985). Confidence limits on phylogenies: an approach using the bootstrap. Evolution 39, 783-791.

Fitch, W. M. (1971). Towards defining the course of evolution: minimum change for a specific tree topology. Syst Zool 20, 406-416.

Glöckner, F. O., Fuchs, B. M. \& Amann, R. (1999). Bacterioplankton compositions of lakes and oceans: a first comparison based on fluorescence in situ hybridization. Appl Environ Microbiol 65, 3721-3726.

Hosoya, S. \& Yokota, A. (2007). Flammeovirga kamogawensis sp. nov., isolated from coastal seawater in Japan. Int J Syst Evol Microbiol 57, 1327-1330.

Katayama-Fujimura, Y., Komatsu, Y., Kuraishi, H. \& Kaneko, T. (1984). Estimation of DNA base composition by high performance liquid chromatography of its nucleae P1 hydrolysate. Agric Biol Chem 48, 3169-3172.

Khan, S. T., Nakagawa, Y. \& Harayama, S. (2007). Sediminitomix flava gen. nov., sp. nov., of the phylum Bacteroidetes, isolated from marine sediment. Int J Syst Evol Microbiol 57, 1689-1693.

Kimura, M. (1983). The Neutral Theory of Molecular Evolution. Cambridge: Cambridge University Press.

Lewin, R. A. (1970). Flexithrix dorotheae gen. et sp. nov. (Flexibacterales); and suggestions for reclassifying sheathed bacteria. Can J Microbiol 16, 511-515.

Ludwig, W. \& Klenk, H.-P. (2001). Overview: a phylogenetic backbone and taxonomic framework for prokaryotic systematics. In Bergey's Manual of Systematic Bacteriology, 2nd edn, vol. 1, pp. 49-66. Edited by D. R. Boone, R. W. Castenholz \& G. M. Garrity. New York: Springer.

Marmur, J. (1961). A procedure for the isolation of deoxyribonucleic acid from micro-organisms. J Mol Biol 3, 208-218.

Muramatsu, Y., Takahashi, M., Kaneyasu, M., lino, T., Suzuki, K. \& Nakagawa, Y. (2010). Persicobacter psychrovividus sp. nov., isolated from shellfish, and emended descriptions of the genus Persicobacter and Persicobacter diffluens. Int J Syst Evol Microbiol 60, 1735-1739. 
Murray, R. G. E., Doetsch, R. N. \& Robinow, C. F. (1994) Determinative and cytological light microscopy. In Methods for General and Molecular Bacteriology, pp. 21-41. Edited by P. Gerhardt, R. G. E. Murray, W. A. Wood \& N. R. Krieg. Washington, DC: American Society for Microbiology.

Nakagawa, Y., Hamana, K., Sakane, T. \& Yamasato, K. (1997). Reclassification of Cytophaga aprica (Lewin 1969) Reichenbach 1989 in Flammeovirga gen. nov. as Flammeovirga aprica comb. nov. and of Cytophaga diffuens (ex Stanier 1940; emend. Lewin 1969) Reichenbach 1989 in Persicobacter gen. nov. as Persicobacter diffuens comb. nov. Int J Syst Bacteriol 47, 220-223.

Nishijima, M., Araki-Sakai, M. \& Sano, H. (1997). Identification of isoprenoid quinones by frit-FAB liquid chromatography-mass spectrometry for the chemotaxonomy of microorganisms. J Microbiol Methods 28, 113-122.

O'Sullivan, L. A., Weightman, A. J. \& Fry, J. C. (2002). New degenerate Cytophaga-Flexibacter-Bacteroides-specific 16S ribosomal DNA-targeted oligonucleotide probes reveal high bacterial diversity in River Taff epilithon. Appl Environ Microbiol 68, 201-210.

Perry, L. B. (1973). Gliding motility in some non-spreading flexibacteria. J Appl Bacteriol 36, 227-232.

Pinhassi, J., Zweifel, U. L. \& Hagström, Å. (1997). Dominant marine bacterioplankton species found among colony-forming bacteria. Appl Environ Microbiol 63, 3359-3366.

Reichenbach, H. (1989). Nonphotosynthetic, nonfruiting gliding bacteria. Genus 1. Cytophaga Winogradsky 1929, 577 ${ }^{\mathrm{AL}}$, emend. In Bergey's Manual of Systematic Bacteriology, 2nd edn, vol. 3, pp. 20152050. Edited by J. Staley, M. P. Bryant, N. Pfennig \& J. G. Holt. Baltimore: Williams \& Wilkins.
Saitou, N. \& Nei, M. (1987). The neighbor-joining method: a new method for reconstructing phylogenetic trees. Mol Biol Evol 4, 406-425.

Srisukchayakul, P., Suwanachart, C., Sangnoi, Y., Kanjana-Opas, A., Hosoya, S., Yokota, A. \& Arunpairojana, V. (2007). Rapidithrix thailandica gen. nov., sp. nov., a marine gliding bacterium isolated from samples collected from the Andaman sea, along the southern coastline of Thailand. Int J Syst Evol Microbiol 57, 2275-2279.

Takahashi, M., Suzuki, K. \& Nakagawa, Y. (2006). Emendation of the genus Flammeovirga and Flammeovirga aprica with the proposal of Flammeovirga arenaria nom. rev., comb. nov. and Flammeovirga yaeyamensis sp. nov. Int J Syst Evol Microbiol 56, 2095-2100.

Tamura, K., Dudley, J., Nei, M. \& Kumar, S. (2007). MEGA4: molecular evolutionary genetics analysis (MEGA) software version 4.0. Mol Biol Evol 24, 1596-1599.

Thompson, J. D., Gibson, T. J., Plewniak, F., Jeanmougin, F. \& Higgins, D. G. (1997). The CLUSTAL_X windows interface: flexible strategies for multiple sequence alignment aided by quality analysis tools. Nucleic Acids Res 25, 4876-4882.

Weisburg, W. G., Barns, S. M., Pelletier, D. A. \& Lane, D. J. (1991). 16 S ribosomal DNA amplification for phylogenetic study. J Bacteriol 173, 697-703.

Yoon, J., Ishikawa, S., Kasai, H. \& Yokota, A. (2007). Perexilibacter aurantiacus gen. nov., sp. nov., a novel member of the family 'Flammeovirgaceae' isolated from sediment. Int J Syst Evol Microbiol 57, 964-968.

Yoon, J., Matsuo, Y., Kasai, H. \& Yokota, A. (2008). Limibacter armeniacum gen. nov., sp. nov., a novel representative of the family 'Flammeovirgaceae' isolated from marine sediment. Int J Syst Evol Microbiol 58, 982-986. 